\title{
KONSEP PENDIDIKAN ANAK USIA DINI BERDASARKAN AL-QUR'AN
}

\author{
Nirwana \\ Universitas Al-Washliyah, Sumatera Utara, Indonesia \\ sugiionno20@gmail.com \\ DOI: 10.20885/tarbawi. vol13.iss2.art5
}

\begin{abstract}
Early childhood education is an important stage to be prepared carefully and conceptually. The verses in the al-Qur'an can be used as a guide in providing the values of early childhood education in an Islamic way to face modern life today. This study aims to discuss early childhood education in the al-Qur'an, stages of early childhood education in the al-Qur'an, Surah Luqman, and the concept of early childhood education in the al-Qur'an, Surah Lukman. This research uses the literature study method. This study found that early childhood education has beneficial roles in life. This study also found seven stages of educating early childhood and six concepts of early childhood education in the al-Qur'an, Surat Luqman. The researcher hopes that this research can be useful for future research in the field of early childhood education from an Islamic perspective.
\end{abstract}

Keywords: Concept, Early Childhood Education, Quran, Luqman

\begin{abstract}
Abstrak
Pendidikan usia dini menjadi tahapan yang penting untuk dipersiapkan secara matang dan terkonsep. Ayat-ayat dalam alQur'an dapat dijadikan pedoman dalam memberikan nilai-nilai pendidikan usia dini secara islami untuk menghadapi kehidupan modern saat ini. Penelitian ini bertujuan untuk membahas pendidikan usia dini dalam al-Qur'an, tahapan pendidikan usia dini
\end{abstract}




\section{$e^{I-T a r b a w j ~ N i r w a n a ~}$}

dalam al-Qur'an, surat Luqman dan konsep pendidikan usia dini dalam al-Qur'an, surat Lukman. Penelitian ini menggunakan metode studi pustaka. Penelitian ini menemukan bahwa pendidikan usia dini memiliki peran urgen dalam kehidupan. Penelitian ini juga menemukan tujuah tahapan mendidik anak usia dini dan enam konsep pendidikan usia dini dalam al-Qur'an, surat Luqman. Peneliti berharap penelitian ini dapat berguna untuk penelitian masa depan bidang pendidikan usia dini dalam perspektif Islam.

Kata Kunci: Konsep, Pendidikan Usia Dini, Al-Qur'an, Luqman

\section{Pendahuluan}

Pelaksanaan pendidikan anak usia dini menjadi prioritas yang sangat penting untuk diperhatikan dalam menjamin tumbuh kembangnya anak sebagai pribadi yang sesuai dengan tuntunan al-Qur'an. Apabila ditelisik secara mendalam, ada beberapa ayat dalam al-Qur'an yang menempatkan kedudukan pendidikan anak usia dini menjadi sangat sentral. Salah satu surat dalam al-Qur'an menyinggung betapa pentingnya keberadaan anak itu sendiri. Seperti yang ada dalam surat AlKahfi ayat 46, Allah berfirman: "Harta dan anak anak adalah perhiasan dalam kehidupan dunia".

Dari firman Allah SWT tersebut, anak digambarkan sebagai perhiasan dimana keberadaannya sangat berharga dan bernilai. Bahkan keberadaanya bisa memberi manfaat bagi orang lain. Kehadiran anak-anak menjadi sebuah berkah, penyejuk jiwa dan rejeki bagi orang tua dan sekelilingnya. Namun demikian, kehadiran anak di sisi yang lain terkadang dianggap beban oleh sebagian orang. Seperti halnya ditemukan dalam beberapa pemberitaan dimana orang tua menelantarkan 
anak-anaknya (Teja, 2014) bahkan tidak segan-segan membunuh anaknya yang ada dalam kandungan atau dalam bahasa yang lain, melakukan aborsi (Pranata, 2012).

Ada sejumlah penelitian yang telah dilakukan oleh beberapa peneliti sebelumnya yang bersinggungan dengan tulisan ini. Penelitian pertama yang telah dilakukan yaitu terkait konsep pendidikan karakter dalam al-Qur'an yang dilakukan oleh Mukhid (Mukhid, 2016). Penelitian lain berkaitan dengan konsep pendidikan hafidz al-Qur'an pada anak usia dini oleh Islamiah dan peneliti lain (Islamiah, 2019) dan pendidikan karakter untuk anak usia dini menurut alQur'an (Mukhlis, 2017).

Maka dari itu, tulisan ini hadir dengan fokus yang berbeda, memperdalam kajian akan pentingnya kehadiran anak dan menambah referensi akan urgensi pendidikan anak usia dini. Lebih dari itu, secara khusus tulisan ini mengkaji dalam perspekif al-Qur'an. Dengan harapan kajian ini bisa menambah pemahaman masyarakat akan pentingnya pendidikan anak. Manfaat dari kajian ini bukan hanya untuk masyarakat muslim tapi juga semua kalangan masyarakat. Karena kehadiran anak di dunia ini menjadi tanggung jawab semua kalangan, tidak memandang perbedaan suku, kepercayaan, agama, dan kelompok tertentu. Terlebih hadirnya seorang anak menjadi titipan dari Allah SWT yang di kemudian hari akan dipertanggung jawabkan. Untuk itulah, sangat penting mengkaji isi dalam al-Qur'an tentang tahapan mendidik anak dan konsep pendidikan.

Berdasarkan latar belakang di atas, secara garis besar rumusan masalah pada tulisan ini adalah bagaimana tahapan 


\section{$e^{I-T a r b a w j ~ N i r w a n a ~}$}

mendidik anak menurut al-Qur'an dan bagaimana konsep pendidikan anak menurut al-Qur'an surah Luqman.

\section{Metode Penelitian}

Metode yang digunakan dalam penelitian ini adalah kajian literatur atau studi pustaka (library research). Studi pustaka menurut Nazir adalah pengumpulan data atau informasi dengan menelaah literatur-literatur, buku-buku, laporan-laporan dan catatan-catatan yang berhubungan dengan masalah yang diteliti atau yang akan dipecahkan (Nazir 2013, 93). Sumber data utama dalam penelitian adalah al-Qur'an yang juga dilengkapi dengan buku-buku dan artikel jurnal. Beberapa kata kunci utama yang digunakan dalam penelitian ini adalah al-Qur'an Surat Luqman dan konsep pendidikan anak. Sumber referensi utama dalam bentuk artikel jurnal yang digunakan dalam penelitian ini berkisar dalam 10 tahun terakhir, kecuali sumber referensi al-Qur'an dan buku pendukung lainnnya yang relevan dimana sudah diterbitkan beberapa tahun sebelumnya.

\section{Hasil Dan Pembahasan}

Secara garis besar, ada tiga topik utama dalam bagian hasil dan pembahasan ini, yaitu pendidikan anak usia dini menurut al-Qur'an, tahapan mendidik anak dalam al-Qur'an, dan kosep pendidikan anak menurut al-Qur'an berdasar surat Luqman. 


\section{Pendidikan Anak Usia Dini Menurut Al-Qur'an}

Al-Qur'an sebagaimana dikemukakan Abd al-Wahhab alKhallaf adalah firman Allah SWT yang diturunkan melalui Malaikat Jibril kepada hati Nabi Muhammad SAW. Al-Qur'an turun dengan menggunakan bahasa Arab dan perlu kajian untuk memahami isi yang terkandung dalam al-Qur'an. Memahami al-Qur'an selain sebagai sarana untuk mendekatkan diri kepada Allah, juga sebagai sarana untuk mendekatkan diri kepada Nabi Muhammad SAW. Salah satu langkah untuk memahaminya adalah dengan cara memabaca isi yang terkandung dalam al-Qur'an. Al-Qur'an sendiri tersusun di antara dua mushaf yang dimulai dengan surah Al-Fatihah dan diakhiri dengan surah An-Nas. Al-Qur'an disampaikan kepada manusia secara mutawatir, baik dari segi tulisan maupun ucapannya. Kehadiran al-Qur'an yang demikian itu telah memberi pengaruh yang luar biasa bagi hadirkan konsep yang mengatur kehidupan umat manusia. Al-Qur'an membahas bermacam persoalan agar manusia bisa hidup sebaik mungkin. Al-Qur'an juga menyajikan solusi dan konsep-konsep dalam kehidupan untuk menjadi umat yang terbaik. Salah satu konsep atau nilai-nilai yang terkandung dalam al-Qur'an adalah mengenai pendidikan (Nata 2016, 1-2). Dilihat dari surat yang pertama kali diturunkan adalah surat yang berkaitan dengan pendidik, yaitu surat al-Alaq ayat 1-5, sebagaimana berikut:

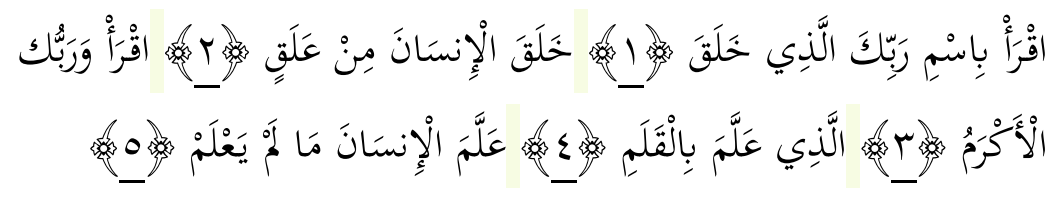




\section{$e^{I-T a r b a w j ~ N i r w a n a ~}$}

Artinya: Bacalah dengan menyebut nama tuhanmu yang menciptakan. Dia telah menciptakan manusia dari 'alaq. Bacalah, dan tuhanmu yang maha pemurah. Yang mengajarkan manusia dengan pena, mengajar manusia apa yang tidak diketahuinya. (Q.S. al-Alaq [96]: 1-5).

Dalam surat al-Alaq ayat 1-5 tersebut, selain Allah memerintahkan umatnya untuk membaca atau mengkaji, juga terkandung pesan untuk mendokumentasikan atau menuliskan ilmu pengetahuan. Setidaknya, umat manusia, dengan membaca dan menulis, selain dapat memproleh informasi yang luas juga dapat menyimpannya untuk jangka waktu yang tidak terbatas. Kemudian dibaca dan diteliti oleh generasi ke generasi yang datang berikutnya. Kegiatan membaca dan menulis dalam arti yang demikian itu menjadi keterampilan yang pertama kali harus diajarkan melalui proses pendidikan dan pengajaran bagi anak-anak. Hal yang demikian dapat dimengerti karena membaca dan menulis dalam arti yang luas itu merupakan kemampuan dasar dalam melakukan kegiatan ilmiah apapun dalam arti yang lebih dalam lagi.

Dilihat dari segi pembawaanya, Nabi Muhammad SAW, juga telah tampil sebagai pendidik. Rasulullah SAW dalam sejarah selain sebagai utusan yang menerima pesan-pesan alQur'an, juga memiliki tugas menyampaikan kandungankandungan al-Qur'an, sehingga umat manusia bisa memahami dan bisa mengamalkannya. Proses dimana Nabi Muhammad mengajarkan dan mengamalkan isi al-Qur'an kepada sahabat menjadi bagian dari pendidikan itu sendiri. Sehingga ketika alQur'an sudah sampai di tengah-tengah masyarakat, menjadi sebuah kewajiban untuk dijarkan kepada anak-anak, agar 
pengetahuan akan Islam bisa mendalam dan mereka bisa mengenal Allah SWT.

Apabila dikaji lebih dalam, ada sekitar 972 kata "rabb" dalam al-Qur'an, yang tersebar di hampir semua surat dalam al-Qur'an, yang pada umumnya berhubungan dengan kata benda (isim), yang dapat diartikan sebagai pemelihara, pendidik. Maka dengan demikian makna "tarbiyah" dapat diartikan sebagai sebuah jalan membimbing dan melejitkan potensi seseorang, baik akal, ruh, dan jasmaninya semaksimal mungkin. Tujuan dari proses ini adalah untuk memberikan bekal kepada umat manusia dalam menghadapi kehidupan di akhirat kelak (Jalaluddin 2003, 72). Penulis tafsir Al-Misbah, Quraisy Shihab memberikan pemaknaan terhadap kata ' $r a b$ ' sebagai Tuhan dengan sifat-sifat-Nya. Dimana Allah sebagai pemelihara, pendidik, pemelihara serta pemberi rahmat, pengampun dosa dan pemberi rejeki kepada manusia (Shihab t.th, 21).

Sehingga dari sini, kata "rabb" dapat memiliki dua makna yaitu pertama bisa dimaknai sebagai Tuhan sekalian umat manusia dan yang kedua memiki kandungan arti sebagai pengasuh, pemelihara dan pendidik. Dalam arti yang lain bahwa Allah sebagai Tuhan yang memiliki sifat memelihara, mengasuh dan mendidik. S ifat inilah yang akan selalu melekat.

Berdasarkan pengertian-pengertian tersebut diatas, maka pendidikan anak menurut al-Qur'an adalah bimbingan, pemeliharaan, pembinaan, pengasuhan terhadap potensi yang dimiliki oleh anak, agar ia dapat tumbuh berkembang secara optimal untuk mencapai tujuan pendidikan yang sesuai dengan ajaran (konsep) al-Qur'an. 


\section{$e^{I-T a r b a w j ~ N i r w a n a ~}$}

\section{Tahapan Mendidik Anak dalam Al-Qur'an}

Peran keluarga khususnya orang tua, memberikan kontibusi dan perhatian masa depan pendidikan anak, karena anak merupakan bagian dari keluarga. Sedangkan keluarga merupakan barometer utama yang sangat menentukan terbentunya masyarakat yang maju atau sebaliknya. Anak adalah generasi penerus bangsa. Peningkatan keterampilan, pembinaan mental, dan moral harus lebih ditingkatkan begitu juga dengan aspek-aspek lainnya. Menghadapi era globalisasi yang ditandai dengan berbagai perubahan tata nilai, maka anak harus mendapat pembinaan intensif dan terpadu yang sesuai dengan tuntuna dalam al-Qur'an sebagai pedoman hidup manusia dari buaian hingga kehidupan kekal yaitu akhirat.

Berikut tujuh tahapan mendidik anak dari mulai kecil sampai dewasa dalam al-Qur'an. Pertama, memilih pasangan yang baik. Allah SWT. mensyariatkan pernikahan untuk menjaga akhlak dan garis keturunan dan kehormatan keluarga. Pernikahan merupakan jalan terbaik untuk menyalurkan energi seksual yang ada pada fitrah manusia dan juga menjadi cara untuk melanjutkan generasi yang lebih baik dan menurunkan sifat baik dari kedua orag tuanya. Allah menjadikan pernikahan sebagai sunah dan Allah menjadikan pernikahan bagi orang yang dikhawatirkan dirinya terjerumus pada perbuatan perzinahan. Hal ini sesuai dengan firman Allah dalam surat An-Nisa ayat 1: 


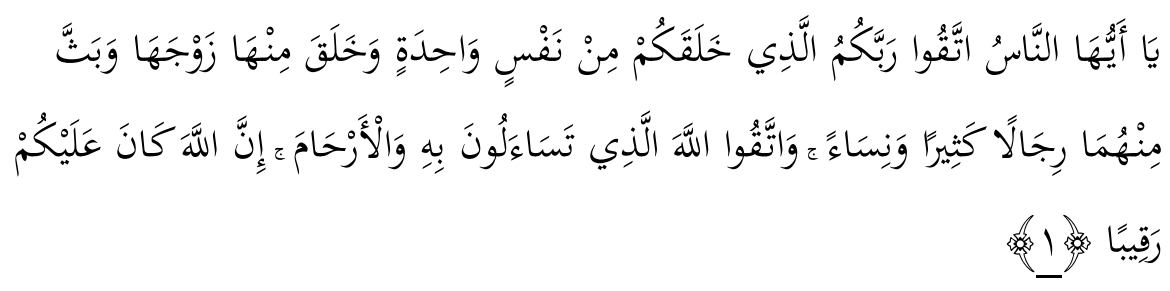

Artinya: Hai sekalian manusia, bertakwalah kepada Tuhanmu yang telah menciptakan kamu dari seorang diri, dan dari padanya Allah menciptakan istrinya dan dari pada keduanya Allah memperkembangiakan laki-laki dan perempuan yang banyak, dan bertakwalah kepada Allah yang dengan mempergunakan nama-Nya kamu saling meminta satu sama lain, dan peliharalah hubungan silaturahim. Sesungguhnya Allah selalu menjaga dan mengawasi kamu. (Q.S An-Nisa [4]: 1)

Kedua, bersyukur atas kelahiran anak. Cara untuk bersyukur atas ketetapan Allah yaitu dengan merawat serta mendidik anak dengan beberapa cara sebagai berikut; mengumandangkan adzan pada telinga sang bayi, memberikan nama yang baik, mengaqiqahi, mengkhitankan anak dan mendidik anak dengan kalimat-kalimat Allah atau (tauhid), mengajarkan berbuat baik.

Ibnu Qayyim R.A memberikan penjelasan bahwa terdapat keistimewaan kepada anak-anak yang lahir kedunia kemudian diperdengarkan dengan adzan dan iqomah. Keistimewaan pertama adalah bagaimana anak yang lahir untuk pertama kalinya di dunia diperdengarkan akan kebesaran dan keagungan Allah SWT sebagai penciptanya. Keistimewaan selanjutnya adalah dengan diperdengarkan adzain dan iqomah anak-anak mulai diperkenalkan dengan kalimat syahadat yang menjadi pintu utama seseorang menjadi seorang Muslim. Sedangkan keistimewaan yang terakhir adalah bagaimana sesorang anak yang lahir diperdengarkan dengan optimisme 


\section{$e^{\text {I-Tarbawj Nirwana }}$}

dan harapan untuk menjadi manusia yang tunduk kepada Allah SWT. Sehingga hadirnya seorang anak sudah sedari awal diberikan tuntunan agar selalu berada di jalan yang benar. Bahkan ketika seseorang meninggal, ia juga kembali diperdengarkan dengan adzan dan iqomah yang menandakan bahwa hadirnya seorang anak di dunia sebagai seorang muslim juga harus meninggal dalam keadaan Islam.

Ketiga, menafkahi anak dengan patut. Sebagai umat Islam haruslah patuh dengan perintah Allah, bahwasannya salah satu hak anak adalah mendapatkan kasih sayang dan juga terpenuhinya kebutuhan dari orang tuanya jika anak dibiarkan tidak makan dan minum, terlebih masih dalam kandungan ibunya, tidak hanya kondisi ibunya saja yang lemah namun janinnya pun akan kekurangan nutrisi dan lemah. Oleh sebab itu menjadi kewajiban kepala rumah tangga untuk memenuhi kebutuhan itu serta anak dalam kandungannya.

Keempat, menyusui anak hingga dua tahun. Dalam alQur'an surat Al-Baqarah ayat 233 Allah memberikan bimbingan kepada para ibu supaya mereka menyusui anakanaknya dengan sempurna, yaitu dua tahun penuh. SSetelah itu, tidak ada penyusuan lagi. Kelima, mengajarkan anak agar beriman kepada Allah. Pendidikan tauhid haruslah ditanamkan kepada anak-anak pada usia dini, dari memperdengarkan kalimat-kalimat Allah, menunjukan kuasa Allah yang ada disekitarnya, serta menanamkan kesesaan Allah. Hal tersebut merupakan bekal yang hakiki dari orang tua kepada anak, agar tujuan anak di dunia bukan untuk mencari kesuksesan dunia semata, namun juga berlandaskan 
iman bahwa segala sesuatu haruslah disandarkan kepada Allah SWT.

Keenam, mengajarkan anak salat pada usia tujuh tahun. Salat wajib ditegakkan untuk seluruh umat Islam yang akan dihisab dan dimintai pertanggungjawabannya kelak di akhirat. Oleh sebab itu, agar seorang muslim tidak meremehkan salat, maka anak dididik sejak dini untuk melaksanakan salat. Ketujuh, mengajarkan akhlak terpuji. Menanamkan pada diri anak sifat rendah hati, menjauhkan dari perbuatan sombong dan angkuh karena manusia merupakan salah satu ciptaan Allah SWT yang memiliki kewajiban untuk menyembah, tunduk dan patuh kepada sang pencipta (Mustoifah 2018, 285290).

Konsep Pendidikan Anak Menurut Al-Qur'an Berdasarkan Surat Luqman

Surah Luqman adalah surah ke-31 dalam al-Qur'an. Nama Luqman diambil dari kisah Luqman bagaimana ia mendidik anaknya. Luqman adalah sosok teladan dalam mendidik anak. Keteladanan Luqman dalam mendidik anak telah diabadikan dalam al-Qur'an agar menjadi contoh dan pedoman bagi umat sesudahnya sebagai amanat sekaligus anugerah dari Allah SWT. Dikisahkan bahwa Lukman tergambar sebagai seorang pendidik yang baik, utamanya kepeduliannya untuk mendidik anaknya. Lukman seringkali memberikan nasehat-nasehat dan selalu mengingatkan anaknya untuk berada dalam jalan yang benar. Dia mengajarkan akhlak terpuji dan pelajaran tentang keimanan. 


\section{$e^{I-T a r b a w j ~ N i r w a n a ~}$}

Berikut enam konsep pendidikan dalam al-Qur'an berdasar Surat Luqman. Pertama, perintah untuk tidak menyetukan Allah SWT. Al-Qur'an menggambarkan nasehatnasehat Lukman seperti yang ada dalam al-Qur'an surat Lukman ayat 13.

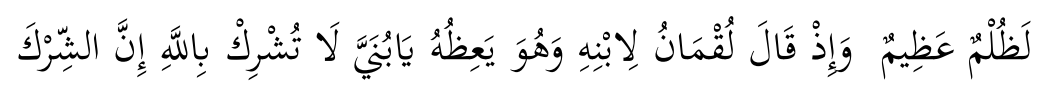

Artinya: Dan (ingatlah) ketika Luqman berkata kepada anaknya, di waktu ia memberi pelajaran kepadanya: "Hai anakku, janganlah kamu mempersekutukan Allah, Sesungguhnya mempersekutukan (Allah) adalah benar-benar kezaliman yang besar". (Q.S. Luqman [31]:13)

Dari sini bisa diambil pemahaman bahwa aspek utama yang perlu diajarkan kepada anak adalah tentang keimanan. Seorang anak harus dididik agar paham tentang Allah SWT dan merawat keimanannya dalam kehidupan sehari-hari. Setidaknya dengan langkah inilah seorang anak selalu dekat dengan penciptanya.

Kedua, ajaran untuk berbakti kepada kedua orang tua. Hal ini tergambar dalam al-Qur'an surat Luqman ayat 14.

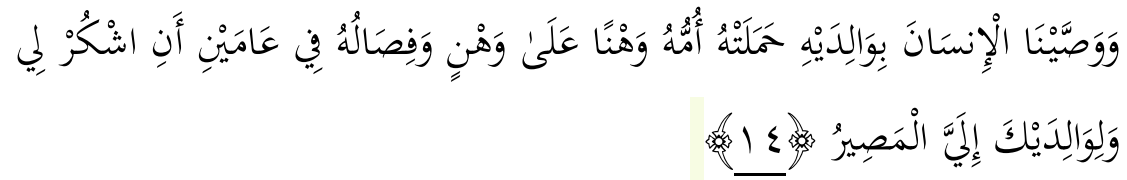

Artinya: Dan Kami perintahkan kepada manusia (berbuat baik) kepada dua orang ibu-bapaknya; ibunya telah mengandungnya dalam keadaan lemah yang bertambah-tambah, dan menyapihnya dalam dua tahun. Bersyukurlah kepadaku dan kepada dua orang ibu bapakmu, hanya kepada-Kulah kembalimu. (Q.S. Luqman [31]: 14).

Lukman mendidik anak-anaknya untuk selalu berbakti kepada ibu dan bapaknya, utamanya kepada ibunya yang telah dengan sabar mengandung anak-anaknya selama lebih dari 
delapan bulan. Demi anaknya, seorang ibu menahan sakit bahkan taruhannya nyawa saat mengandung dan melahirkannya. Sedangkan sebagai sesorang bapak, ia berusaha dengan keras untuk mencari nafkah untuk keluarganya. Sehingga tidak ada kata lain bagi anak-anaknya untuk selalu berbakti kepada kedua orang tuanya.

Ketiga, ajaran untuk mengikuti perintah baik dari orang tua dan menolak perintah yang tidak baik. Sebagaimana tergambar dalam al-Qur'an Surat Luqman ayat 15.

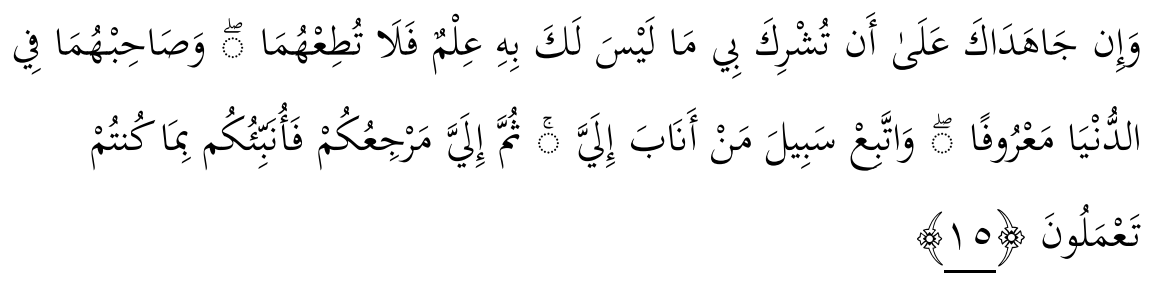

Artinya: Dan jika keduanya memaksamu untuk mempersekutukan dengan aku sesuatu yang tidak ada pengetahuanmu tentang itu, Maka janganlah kamu mengikuti keduanya, dan pergaulilah keduanya di dunia dengan baik, dan ikutilah jalan orang yang kembali kepada-Ku, kemudian hanya kepadaKulah kembalimu, Maka Kuberitakan kepadamu apa yang telah kamu kerjakan. (Q.S. Luqman [31]: 15)

Ayat di atas memiliki makna yang tidak terpisahkan dengan ayat yang mendahuluinya, dimana sesorang anak diperintahkan untuk taat kepada kedua orang tuanya. Namun demikian, seorang anak tidak perlu mengikuti perintah kedua orang tuanya apabila perintah tersebut bertujuan untuk bertindak buruk. Terlebih perintah untuk tidak menduakan Allah atau menyekutukan-Nya. Akan tetapi meskipun seorang anak berseberangan paham dengan orang tuanya, ia tetap harus menghormati kedua orang tua tersebut. Alasanya adalah karena keberadaan seorang anak di dunia tidak lepas dari 


\section{$e^{I-T a r b a w j ~ N i r w a n a ~}$}

keberadaan kedua orang tua, terlebih mereka sudah melahirkan dan membesarkannya.

Keempat, setiap perbuatan akan mendapatkan balasan. Konsep ini tergambar dalam Al-Qur'an Surat Luqman ayat 16.

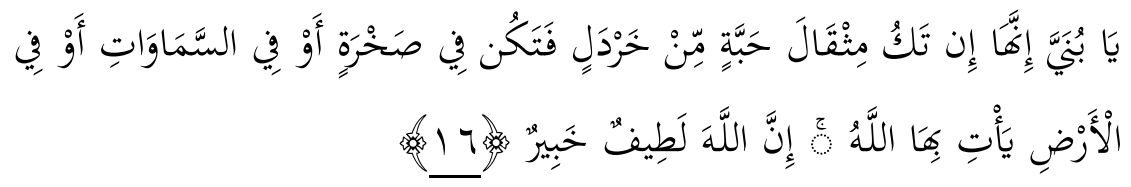

Artinya: (Luqman berkata) "Hai anakku, Sesungguhnya jika ada (sesuatu perbuatan) seberat biji sawi, dan berada dalam batu atau di langit atau di dalam bumi, niscaya Allah akan mendatangkannya (membalasinya). Sesungguhnya Allah Maha Halus [2] lagi Maha mengetahui. (Q.S. Luqman [31]: 16)

Firman Allah SWT di atas mengandung pesan untuk menjauhi tindakan tercela dan dianjurkan selalu berbuat kebaikan. Setiap tindakan, baik itu baik atau pun buruk akan mendapatkan balasannya. Tentu perbuatan baik akan menuai kebaikan, sebaliknya perbuatan tercela akan mendatangkan malapetaka. Allah SWT juga Maha tahu dan Maha adil terhadap umat manusia. Sehingga segala perbuatan manusia akan dipertanggung jawabkan.

Kelima, mendirikan salat, amar makruf nahi mungkar dan sabar. Konsep ini ada dalam al-Qur'an Surat Luqman ayat 17.

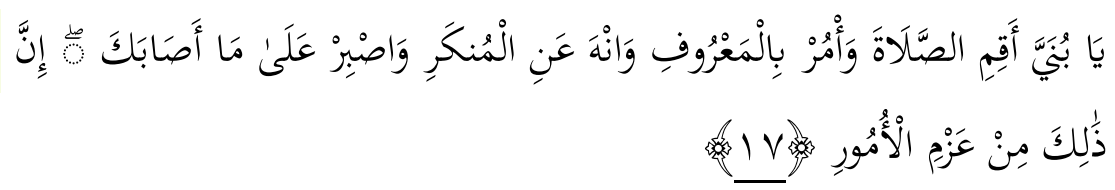

Artinya: Hai anakku, dirikanlah shalat dan suruhlah (manusia) mengerjakan yang baik dan cegahlah (mereka) dari perbuatan yang mungkar dan bersabarlah terhadap apa yang menimpa kamu. Sesungguhnya yang 
demikian itu termasuk hal-hal yang diwajibkan (oleh Allah). (Q.S. Luqman [31]: 17)

Dalam firman Allah SWT di atas, Lukman selalu mengingatkan anaknya untuk menjalankan salat lima waktu. Lebih dari itu, Lukman menyerukan kepada anaknya untuk mengedepankan tindakan yang baik dan menjauhi perbuatan mungkar. Pesan selanjutnya adalah dimana Lukman menyerukan kepada anaknya untuk selalu sebar dalam menghadapi semua cobaan dari Allah SWT.

Keenam, jangan sombong. Konsep ini ada dalam al-Qur'an Surat Luqman ayat 18.

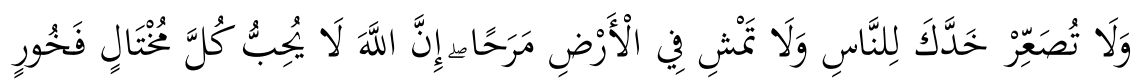

Artinya: Dan janganlah kamu memalingkan mukamu dari manusia (karena sombong) dan janganlah kamu berjalan di muka bumi dengan angkuh. Sesungguhnya Allah tidak menyukai orang-orang yang sombong lagi membanggakan diri. (Q.S. Luqman [31]: 18)

Dari ayat di atas juga bisa dipahami bahwa Lukman mengajak anaknya untuk tidak memilki sikap yang sombong. Terlebih Allah SWT tidak menyukai sikap orang yang sombong. Dari sini, Lukman digambarkan sebagai orang tua yang memberikan pendidikan yang baik kepada anaknya. Sebagai orang Muslim, sudah sepantasnya menerapkan pendekatan dan metode pengajaran dalam pendidikan sesuai yang dilakukan oleh Lukman dimana untuk seslalu berbuat baik. Berbuat baik kepada Allah, kepada kedua orang tua, dan kepada seluruh umat manusia (Tim Penerbit Ma'sum 2017, 412). 


\section{$e^{\text {I-Tarbawj Nirwana }}$}

Pada hasil dan pembahasan di atas dapat digaris bawahi bahwa pendidikan anak usia dini adalah proses pembinaan, pemeliharaan, pembimbingan, dan pengasuhan terhadap potensi yang dimilikinya agar dapat tumbuh dengan optimal sesuai dengan ajaran al-Qur'an. Tahapan mendidik anak meliputi tujuh tapahan, yaitu memilihkan pasangan yang baik, bersyukur atas kelahiran anak, menafkahi anak dengan patut, menyusui anak sampai berumur dua tahun, mengajajrkan anak beriman kepada Allah, dan mengajarkan anak salat pada ussia tujuh tahun. Sedangkan konsep mendidik anak menurut alQur'an surat Luqman setidaknya meliputi enam konsep, yaitu perintah untuk tidak menyekutukan Allah, ajaran untuk berbakti kepada kedua orang tua, ajaran untuk mengikuti perintah baik dari orang tua dan menolak perintah yang tidak baik, setiap perbuatan akan mendapatkan balasan, mendirikan salat, dan konsesp untuk tidak sombong.

\section{Kesimpulan}

Pendidikan anak usia dini memiliki peranan penting dalam kehidupan sehari-hari. Pendidikan anak usia dini bukan hanya berkaitan proses mengasuh dan memelihara, akan tetapi juga langkah-langkah membimbing untuk melejitkan potensi anak agar menjadi pribadi yang paripurna, yaitu sesuai dengan tuntunan al-Qur'an. Pola pendidikan yang terkandung dalam surah Luqman merupakan pola pendidikan yang islami, pola pendidikan yang berbasiskan pada keislaman.

Komponen-komponen yang terkandung dalam surah Luqman, antara lain adalah pendidik, peserta didik, materi 
pendidikan, metode pendidikan. Pendidik yang digambarkan dalam al-Qur'an adalah kisah Lukman sebagai orang tua dan anaknya selaku peserta didik. Sedangkan materi dalam pendidikannya memuat seputar aqidah, syariah, dan akhlaqul karimah. Selanjutnya metode dalam mendidiknya adalah dengan cara-cara yang baik, yaitu dengan memberikan nasehat moral.

\section{Daftar Pustaka}

Mukhid, Abd. (2016). Konsep Pendidikan Karakter Dalam al-Qur'an. NUANSA: Jurnal Penelitian Ilmu Sosial dan Keagamaan Islam, Vol. 13 (2) 309-328.

Jalaluddin. (2003). Teologi Pendidikan. Jakarta: PT. Raja Grapindo Persada.

Mukhlis, G.N. (2017). Pendidikan karakter untuk anak usia dini menurut QS Lukman: 13-19. PEDAGOGI: Jurnal Anak Usia Dini Dan Pendidikan Anak Usia Dini, 3(3a).

Mustoifah, dkk. (2018). Teori dan Aplikasi dalam Penafsiran Ayat Pendidikan. Yogyakarta: Diandra Kreatif.

Nata, Abuddin. (2016). Pendidikan dalam Perspektif AlQur'an. Jakarta: Prenada Media Group.

Nazir, Moh. (2013). Metode Penelitian. Bogor: Ghalia Indonesia.

Pranata, S. and Sadewo, F.S. (2012). Kejadian keguguran, kehamilan tidak direncanakan dan pengguguran di Indonesia. Buletin Penelitian Sistem Kesehatan, 15(2), p.21342.

Shihab, M. Quraish. (Tanpa Tahun). Mahkota Tuntunan Ilahi. Jakarta: Untagama.

Teja, M. (2014). Perlindungan terhadap anak terlantar di panti asuhan. Info Singkat Kesejahteraan Sosial, 6. 


\section{$e^{\text {I-Tarbawj Nirwana }}$}

Tim Penerbit Ma'sum. (2017). Al-Qur'an Terjemah Ma'sum. Surakarta: Ma'sum. 